\title{
viewpoint Do we need a new manifesto for an art libraries society?
}

First of all an apology is in order for everyone who was expecting a special fashion issue. I had to split issue three into issues three and four to avoid going over our total page count, which pushes the fashion issue into 2017. I promise, though, it is coming.

The splitting of issues means I need to find another viewpoint piece and time is short to acquire it. This gives me the opportunity, once again, to re-visit the early issues of the Art libraries journal in our 40th anniversary year. Over the past few months I have been involved in ARLIS Council's membership review group. The following views are my own and I'm not representing ARLIS or the membership review group. But I have felt driven to speak of my sadness that we even have come to this point.

It is no secret that ARLIS/UK \& Ireland has been losing personal members over several years as the profession has changed.

Examining the challenges that face ARLIS and the possible solutions is an emotional exercise. Like many other professional groups and societies, we are faced with dwindling income and a dearth of volunteers to undertake the organizational and governance activities of the Society. We must contemplate ARLIS's sustainability and it is a tremendous burden to bear. This Society, the first to represent art libraries independent of a larger national library organization, ${ }^{1}$ has almost 50 years of knowledge and experience of supporting and developing the interests of art libraries and art librarians.

Could it really be that this Society that has served as a model for art libraries around the world and played a crucial role in the careers of most of the art librarians I know, is now obsolete? Responses to our membership survey suggests it still plays a vital role in professional development for staff working in art libraries. As editor of this journal, I sometimes meet with international colleagues at conferences or symposia and they remind me of the esteem in which ARLIS/UK \& Ireland is held. I know how much time and energy all the members of committees, council and, yes, editors donate to ARLIS, in addition to their hectic day jobs and their demanding lives outside of the profession, to mentor, to provide interesting and relevant workshops, visits, conferences and professional literature. What they all have done to build ARLIS over the past 46 and a half years should not come to nought, because its aims are still pertinent.
1. Philip Pacey. "Manifesto for an art libraries society", Art libraries journal 8:4 (winter 1983): 5. 
I turn to Philip Pacey's 'Manifesto for an art libraries society' from winter 1983. His five-point programme for an art library society still rings true today:

'Make sure that your association welcomes every type of art librarian and every category of art library.' ${ }^{2}$ I would include paraprofessional staff, as well, and members of other professions who now find themselves working in libraries, such as archivists, IT and digitization staff.

'Examine the provision of art publications and information in your country.' ${ }^{3}$ As art publishing has expanded, in print and digitally, are we confident that our libraries collect exhaustively the documentation of contemporary art produced and exhibited in the UK and Ireland?

'Consider your country's art libraries and art documentation collections as a whole.'4 Have all collections been catalogued online? Do libraries co-ordinate their collecting or is there a lot of duplication across the network? Is there a co-operative strategy for the decommissioning of slide collections or of documenting artists' ephemera?

'Make contact with art librarians in other countries, and above all, participate in the work of the IFLA Section of Art Libraries. ${ }^{5}$ Is there institutional support in art libraries for national and international conference attendance, not just the ARLIS conference? Are you encouraged and supported to take advantage of webinars and other practice-sharing opportunities?

'Seek also to develop and renew your awareness of and commitment to the purpose of art librarianship.' ${ }^{6}$ Do you visit exhibitions or degree shows to view art? Are you supported to attend book fairs? Do you have to do these external activities in your own time, on vacation, or are you encouraged to engage with the subjects you advise on during your work day?

If we agree with Pacey that the role of art libraries is to '...further the study of art, the enjoyment of art, and the creation of $\mathrm{art}^{\prime 7}$, it is an ongoing mission and there is still plenty of work to do. If ARLIS in the UK ceases to exist, I have no doubt that it would need to be re-invented soon after. So, let's bypass the middle man and re-invent the Society ourselves and respect that 50 year legacy. Everyone who works in an art library today has a role to play. If you don't think ARLIS represents you and your work, why not get involved to help change it?

Erica Foden-Lenahan

aljeditor@gmail.com
2. Pacey (1983): 7.

3. Pacey (1983): 8.

4. Pacey (1983): 9.

5. Pacey (1983): 10.

6. Pacey (1983): 12.

7. Pacey (1983): 4. 